\title{
PELATIHAN PENGGUNAAN APLIKASI SOCIAL LEARNING NETWORK BERBASIS EDMODO UNIVERSITAS MUHAMMADIYAH MAKASSAR
}

\author{
Sri Satriani $1^{*}$ \\ Baharullah $^{2}$ \\ Sirajuddin ${ }^{3}$ \\ 1,2,3 Universitas Muhammadiyah Makassar, Makassar, Indonesia \\ srisatriani@unismuh.ac.id ${ }^{1 *}$ \\ baharullah@unismuh.ac.id ${ }^{2)}$ \\ sirajuddin@unismuh.ac.id ${ }^{3}$ )
}

Kata Kunci: [Pelatihan, Edmodo]

\begin{abstract}
Abstrak: Pandemi Covid 19 masih melanda Sebagian besar negara diberbagai belahan dunia termasuk Indonesia. Hal tersebut mengharuskan pembelajaran menggunakan pembelajaran dalam jaringan yang memudahkan proses belajar mengajar. Berbagai macam aplikasi pembelajaran dapat digunakan untuk melakukan proses pembelajaran daring salah satunya adalah Aplikasi Edmodo yang fiturnya mirip dengan facebook sehingga sangat mudah digunakan oleh pemula. Pengabdian ini memberikan pelatihan penggunaan aplikasi Edmodo pada program studi Pendidikan matematika Univeritas Muhammadiyah Makassar pada kelas kalkulus. Mahasiswa yang berpartisipasi dalam kegiatan ini berjumlah 50 orang yang terdiri atas dua kelas.
\end{abstract}

\section{Pendahuluan}

Seiring berkembangnya ilmu pengetahuan dan teknologi di era digital seperti sekarang ini, semakin berkembang pula sistem pembelajaran yang digunakan dengan memanfaatkan media online sebagai salah satu sarana yang dapat dipakai para akademisi dalam proses belajar mengajar. Kegiatan belajar mengajar tidak lagi dibatasi oleh jarak dan waktu. Proses belajar mengajar yang biasanya dilakukan di dalam kelas, sekarang dapat dilakukan dimana saja dan kapan saja. Guru dapat membuat kelas virtual sendiri sehingga dapat tetap berinteraksi dengan siswa mereka dalam kelas maya walaupun tidak langsung bertatap muka. Ini yang biasa disebut dengan Distance Learning (pembelajaran jarak jauh) yang dapat digunakan untuk mengatasi permasalahan yang sulit diatasi dengan cara konvensional.

Pembelajaran di ruang kelas online memang tidak dapat dijadikan sebagai penggati seutuhnya pembelajaran tatap muka di dalam kelas, akan tetapi pembelajaran menggunakan kelas online akan sangat bermanfaat pada saat- saat tertentu. Misalnya seseorang yang harus bekerja sambil sekolah, sehingga sekolah online menjadi salah satu ruang bagi mereka untuk tetap belajar seperti halnya di dalam kelas. Begitupun permasalahan global yang sedang dihadapi oleh masyarakat dunia saat ini yakni pandemi wabah COVID-19 yang melanda beberapa Negara di dunia. Salah satu yang terkena dampak pandemi wabah tersebut adalah Indonesia sendiri. Hal ini yang kemudian memaksa warga untuk melakukan social distance (menjaga jarak) agar wabah tidak 
semakin menyebar. Secara otomatis, kegiatan pembelajaran yang sejatinya dilakukan di dalam kelas, berubah haluan menjadi kegiatan pembelajaran yang dilakukan secara online dengan memanfaatkan berbagai macam applikasi virtual learning yang tersedia. Saat ini aplikasi yang digunakan oleh para akademisi untuk membuat kelas mereka adalah menggunakan google classroom, zoom cloud meeting dan lainnya. Akan tetapi applikasi diatas hanya digunakan oleh orang-orang yang memiliki keingintahuan lebih banyak karena fitur-fitur yang tersedia banyak sehingga menyulitkan masyarakat awam untuk memakainya. Sebenarnya banyak media jejaring sosial pembelajaran (Sistem Learning Network) yang menawarkan berbagai macam kemudahan, namun memang belum familiar digunakan dibanding google classroom. Berdasarkan hasil penelitian yang kami lakukan beberapa waktu lalu terkait dengan salah satu aplikasi media pembelajaran online yaitu aplikasi Edmodo, kami mendapatkan kesimpulan bahwa Edmodo dapat menjadi salah satu media pembelajaran yang dapat meningkatkan kemandirian dan keaktifan mahasiswa dalam belajar.

Edmodo adalah salah satu media sosial yang sering digambarkan sebagai facebook pembelajaran (Warjanto dkk,2014). Tampilan Edmodo mengadaptasi dari facebook sehingga lebih mudah untuk digunakan. Edmodo dirancang dengan menggabungkan beberapa fitur Learning Management System (LMS) dan Sosial Learning Network (SLN) yang khusus dibuat untuk keperluan pendidikan (Edmodo,2020). LMS sendiri adalah portal yang menghubungkan guru dan murid sehingga dapat dengan mudah membagikan materi pelajaran atau tugas di luar sekolah. Sedangkan SLN sendiri adalah rung virtual dimana orang dari minat yang sama berkumpul untuk berkomunikasi, berbagi dan mendiskusikan ide-ide satu sama lain (Wang dkk, 2012). Beberapa fitur pembelajaran disediakan seperti diskusi dalam satu kelompok atau kelas, catatan, pengumpulan tugas kuis, polling, sharing materi dan lain-lain. Selain itu kelebihan dari Edmodo adalah orang tua juga dapat mengambil peran untuk melakukan pengawasan serta memantau perkembangan proses belajar putra-putrinya melalui aplikasi Edmodo.

Prodi Pendidikan Matematika menjadi salah satu prodi yang menyelenggarakan pembelajaran daring selama pandemic Covid-19. Ada banyak aplikasi yang dibebaskan pada Dosen untuk menggunakannya sepanjang pembelajaran dapat berlangsung seperti biasanya. Beberapa diantaranya menggunakan Google Classroom, Google Meet, Zoom, dan Spada. Akan tetapi masih sangat kurang yang menggunakan aplikasi Edmodo untuk menunjang pembelajaran berbasis Jaringan. Mahasiswa juga masih sangat asing dengan Aplikasi ini sehingga mendorong kami untuk mengadakan pelatihan sekaligus implementasi penggunaan aplikasi Edmodo pada mahasiswa prodi Pendidikan matematika pada mata kuliah Kalkulus.

\section{Metode Pelaksanaan}

\section{Tahap Persiapan}

Pada tahap persiapan, kegiatan yang akan dilakukan oleh tim pengabdian diantaranya sebagai berikut:

a. Pengurusan kelengkapan administrasi termasuk persuratan pada pihak yang berwenang untuk mengetahui pelaksanaan kegiatan pengabdian

b. Berkoordinasi dengan mitra terkait dengan hal-hal yang dianggap penting dan diperlukan untuk kelancaran kegiatan ini. Sarana dan prasarana yang dibutuhkan 
serta kesepakatan mengenai persyaratan menjadi peserta dalam kegiatan ini dan batas kuota peserta yang ingin terlibat. Tim pengabdian akan membuat formulir untuk peserta

c. Menyiapkan materi persentasi pada saat pelatihan

d. Menyiapkan jadwal pelaksanaan pelatihan sekaligus implemntasi dari penggunaan Aplikasi Edmodo pada Mahasiswa Prodi Pendidikan Matematika.

\section{Tahap Pelaksanaan}

Sebelum memulai kegiatan praktikum, terlebih dahulu diawali dengan pengenalan SLN dan aplikasi Edmodo melalui web dan mobile. Pengenalan ini digunakan untuk membantu guru dalam menggunakan media pembelajaran dengan aplikasi Edmodo. Tim pengabdian akan membuat panduan atau modul tentang cara penggunaan SLN berbasis Edmodo dan akan dibagikan pada seluruh peserta kegiatan. Pembagian materi kegiatan dilakukan dua sesi yakni:

a. Sesi 1 untuk materi Edmodo berbasis website, pembuatan kelas, pembuatan catatan, share materi, membuat tugas, dan membuat kuis kemudian evaluasi

b. Sesi 2 untuk materi Edmodo berbasis mobile, pembuatan catatan, share materi, membuat tugas dan membuat kuis melalui perangkat smartphone kemudian dilakukan evaluasi.

\section{Tahap Akhir Kegiatan}

Evaluasi keberhasilan kegiatan pelatihan dilakukan setelah masing-masing sesi dan juga pada akhir kegiatan. Indikator keberhasilan kegiatan dilihat dari respon positif dari peserta kegiatan melalui Evaluasi yang diberikan. Kegiatan evaluasi juga dilakukan dengan membagikan kuisioner yang diisi peserta, terkait dengan kegiatan yang telah diikuti. Peserta juga akan diberikan sertifikat sebagai bukti keikutsertaan dalam pelatihan ini..

\section{Hasil dan Pembahasan}

Pelatihan implementasi pembelajaran daring menggunakan aplikasi Edmodo Untuk prodi Pendidikan matematika di mata kuliah kallkulus diikuti oleh 50 orang mahasiswa yang terdiri dari 2 kelas.

1. Pengenalan aplikasi Edmodo

Pada tahap ini dilakukan pengenalan secara umum aplikasi Edmodo yang dapat mahasiswa install pada laptop ataupun smartphone masing-masing. Cukup mengklik Edmodo (Lihat Gambar 1).

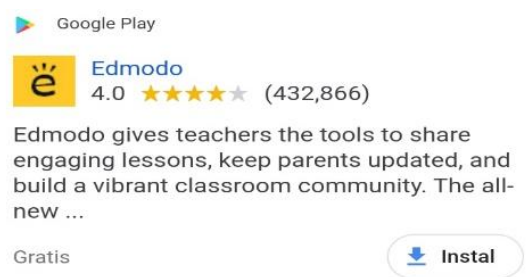

Gambar 1. Aplikasi Edmodo 
2. Cara membuat akun Edmodo

Tahap ini dijelaskan mengenai cara membuat akun Edmodo pada halaman depan Edmodo sebelah kanan terdapat tulisan mendaftar, mahasiswa mengklik itu untuk membuat akun masing-masing. Setelah itu terdapat halaman yang dapat dipilih sebagai akun guru, akun siswa ataupu akun orang tua (Lihat Gambar 2).

\section{edmodo}

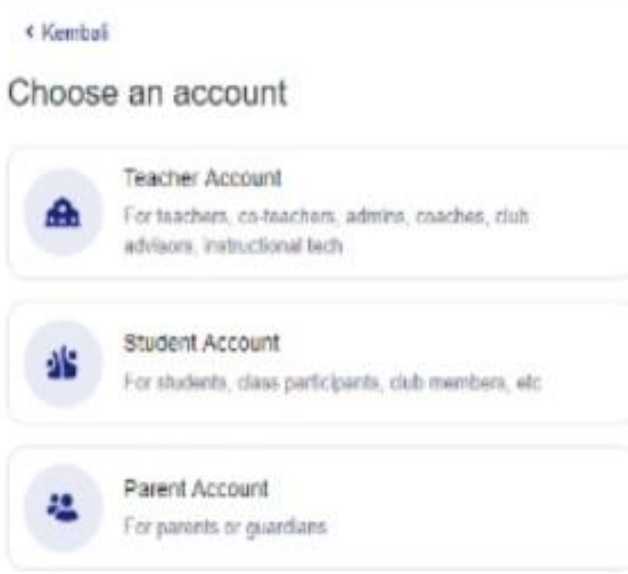

Gambar 2: Cara Membuat Akun Edmodo

Mahasiswa dapat mengklik student account. Pengguna kemudian diarahkan untuk membuat nama sesuai dengan nama mahasiswa yang lengkap sehingga memudahkan pengajar untuk melakukan penilaian. Setelah itu siswa akan diminta untuk melengkapi profil akun yang dibuat, seperti nama belakang dan nama depan siswa. Setelah itu tombol selesai dapat diklik oleh mahasiswa (Lihat Gambar 3).

edmodo

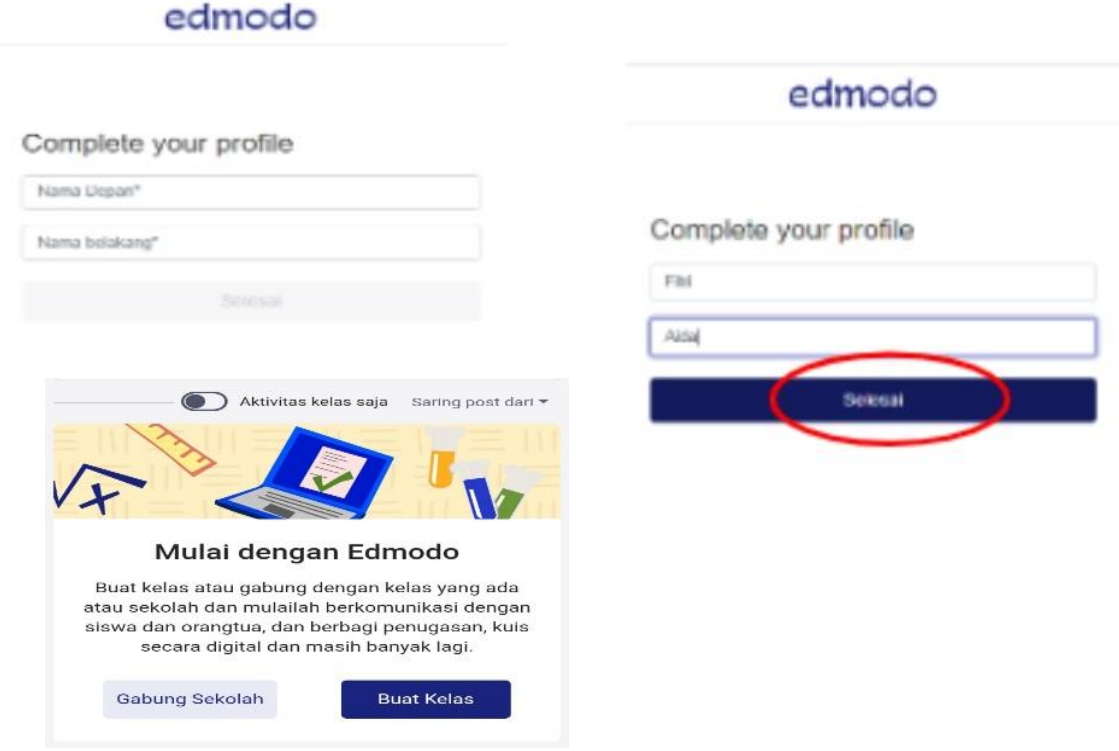

Gambar 3: Akun Edmodo 


\section{Pengenalan fitur Edmodo}

Setelah mahasiswa dapat masuk ke akun masing-masing pada aplikasi Edmodo, selanjutnya mahasiswa kemudian diperkenalkan fitur-fitur yang ada diaplikasi pada halaman beranda seperti mengisi survey kehadiran, memasukkan materi, diskusi, upload tugas dan lain sebagianya.

4. Implementasi aplikasi Edmodo oleh mahasiswa

Setelah diperkenalkan fitur-fitur yang ada pada aplikasi Edmodo, mahasiswa kemudian diberikan kesempatan untuk mencoba mempraktekkan penggunaan Edmodo pada mata kuliah kalkulus berikut ditampilkan gambar dari kegiatan mahasiswa pada aplikasi Edmodo (Lihat Gambar 4).
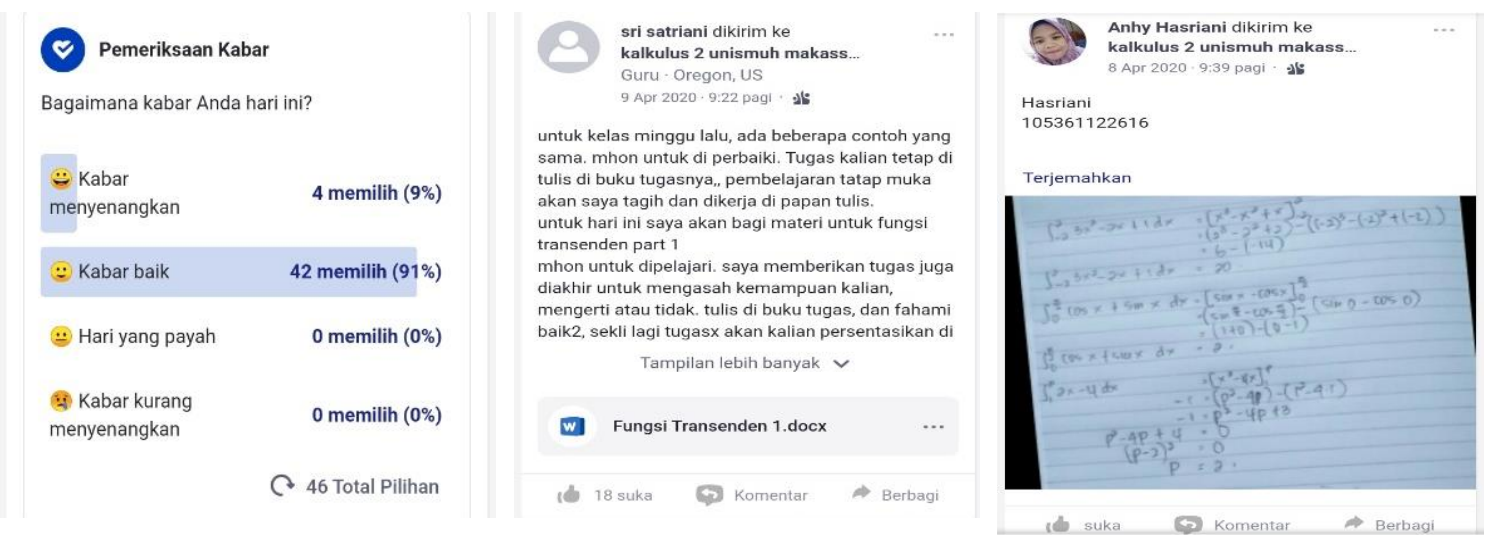

Gambar 4. Implementasi aplikasi Edmodo oleh mahasiswa

\section{Kesimpulan}

Pelatihan Penggunaan Aplikasi Edmodo merupakan bentuk pengabdian untuk memperkenalkan salah satu aplikasi yang dapat dijadikan alternatif pembelajaran dalam jaringan yang mudah digunakan oleh pemula sekalipun. Fitur yang mirip dengan facebook akan sangat familiar oleh pengguna sehingga dapat memudahkan dalam proses belajar mengajar. Bukan hanya pengajar dan peserta didik yang dapat terlibat dalam aplikasi ini, akan tetapi orang tua dapat mengawasi jalannya pembelajaran dan mengontrol aktivitas anak mereka masing-masing dengan menggunakan aplikasi Edmodo. Prodi Pendidikan matematika telah menjadikan Edmodo menjadi salah satu aplikasi yang digunakan dalam pembelajaran secara daring selain SPADA, Google Classroom, zoom dan lain sebagainya.

\section{Ucapan Terimakasih}

Terimakasih kami ucapkan kepada pihak Dekan FKIP Universitas Muhammadiyah Makassar dan Wakil Dekan Bidang Akademik yang telah memberikan kesempatan kepada penulis untuk melakukan pengabdian kepada masyrakat (PKM) dilingkup FKIP UNISMUH Makassar.

\section{Referensi}

Edmodo, https://www.edmodo.com/about, diakses pada tanggal 3 maret 2020 
Vol. 1. No. 1, Mei 2021

Warjanto., Setyo.,Nurhayati., Ashar,Anugrah, 2014. Efektivitas Social Learning Network Edmodo Terhadap Hasil Belajar Siswa SMA Materi Alat Optik, Prosiding Fisika UIN 2014. Jakarta.

Wang,Qiyun, Woo,Huay Lit.,Yang,.Yuqin.,Mei.,2012. Using The Facebook Group As A Learning Management System Learning Management System: An explatory study, British Jornal of Educational Technology Vol 3.No.3 